Article

\title{
Reason, Rhythm, and Rituality. Reinterpreting Religious Cult from a Postmodern, Phenomenological Perspective
}

\author{
Martina Roesner \\ Katholisch-Theologische Fakultät, Institut für Bibelwissenschaft (Altes Testament), University of \\ Vienna, Schenkenstraße 8-10, A-1010 Wien, Austria; E-Mail: martina.roesner@univie.ac.at; \\ Tel.: +43-1-4277-30418; eFax: +43-1-4277-830418
}

Academic Editor: Jonathan Hill

Received: 4 May 2015 / Accepted: 17 June 2015 / Published: 10 July 2015

\begin{abstract}
Contemporary philosophy of religion is often focused, at a theoretical level, on the epistemic value of religious doctrines, and at a practical level, on the possible impact of organized religion on secular society and politics. However, the cultic dimension of religion, such as prayer, religious service, ascetic practices, and other rituals, is considered as completely "irrational" and incomprehensible from a secular perspective and therefore often neglected by postmodern philosophy. The paper intends to call into question this rather simplistic interpretation by retracing the historical origins of the devaluation of religious symbolism in occidental thought, which culminates in Kant's philosophy of religion. We then shall analyze to what extent certain paradoxical aspects of Habermas' view on religion can be interpreted as consequences of the dilemma brought about by the Kantian dichotomy between man as moral subject and man as natural, sensible being. In a third step, we shall develop an alternative, phenomenological interpretation, which does not consider religious practice as a primitive, irrational phenomenon but as a proto-ethical schematism that aims at integrating the sphere of pure practical reason into the rhythmic structure of living, embodied consciousness.
\end{abstract}

Keywords: philosophy of religion; postmodern philosophy; phenomenology; religious rituals; ethics; mind-body problem; language and rationality; Jürgen Habermas; Immanuel Kant; Edmund Husserl 


\section{Introduction}

Over the past ten to fifteen years, the question concerning the role of religion in a secular society has gained unexpected importance, not only from a pragmatic or social point of view but also and perhaps even more so from a philosophical perspective. Though sparked at first by external, political events ([1], pp. 9-12), the renewed interest in the religious phenomenon has soon incited a debate that aims at a critical reflection on the tacit, and sometimes not unproblematic, assumptions and presuppositions secular rationality has hitherto felt perhaps a little too comfortable with. Habermas' recent works dedicated to this topic prove quite convincingly that even for staunch defenders of the philosophical ideals of Enlightenment, religion is not necessarily to be considered as a primitive state of consciousness, which openly contradicts the values of modern society. Rather, it is often described as a possible source of insights which, once translated into a secular conceptuality, may become of theoretical and practical relevance even to non-believers ([2], p. 118; [3], pp. 136-38).

Strangely enough, though, the debate is almost exclusively focused on the "cognitive contents", the "epistemic status", and the "semantic potential" of religious or theological discourse ([2], pp. 107, 109, 118; [3], pp. 143, 149; [4], pp. 254-55). This creates the impression that religion is primarily a theoretical world-view that secondarily entails ethical commandments and prohibitions, whose practical impact on everyday life may or may not be compatible with the legal framework of a liberal, democratic society. The fact that religion, as a rule, is neither a purely theoretical doctrine nor a mere collection of ethical guidelines but also expresses itself in cultic practices and rituals is either ignored or simply considered as an archaic, mythological residue which resists the translation into a universally understandable conceptuality and thus remains irrelevant to philosophical reason [5]. As a consequence, the various forms of religious worship are merely tolerated by a secular society on the condition that they do not violate the basis of common law, and especially the fundamental principle of human dignity. While it is perfectly reasonable to expect religion to conform to this minimal common denominator of legality, posing a merely negative limit to religious practice is, however, largely insufficient to grasp its true essence. In fact, it makes appear the whole sphere of religious rites and practices as a legally domesticated phenomenon of irrationality, which, from a secular viewpoint, may at best be considered innocuous but is not taken seriously as a potential source for universally relevant insights.

In this paper, both this position and its theoretic fundaments shall be analyzed and challenged before offering a possible alternative interpretation of religious practice. Before entering the core of the subject, however, we would like to make some conceptual clarifications. The most important and perhaps also the most difficult one concerns the term "religion" itself. This concept covers such a vast range of phenomena in so many different cultural spheres that it is virtually impossible to use it without any further specification. In the context of our present paper, its specific meaning is determined by the authors we have chosen to examine. Both Kant and Habermas often talk about "religion" in general while referring in fact to the Biblical, Judeo-Christian tradition or even to specific Christian denominations, like Protestantism or Catholicism. It goes without saying that this particular concept of "religion" would be insufficient or even inappropriate to describe most forms of religious practice in other parts of the world. However, it is a simple fact that in occidental thought, the question concerning the relationship between "faith and reason" has developed in the critical dialogue of 
Greco-Roman philosophy, not with just any religion but with the Biblical, theist tradition in general and Christianity in particular. Of course, one could criticize both Kant and Habermas for having such a tacitly "Eurocentric" preconception of religion, but this is at present not our issue. Given the topic of our paper, we shall work with their particular use of the term "religion" as synonymous with the Biblical, Christian tradition, without making any normative claim as to the applicability of this concept to other religions.

The second clarification concerns the meaning of the term "postmetaphysical". It will be used in the broad sense, i.e., as referring to all those currents of thought for which, in the wake of Heidegger's criticism of occidental metaphysics, both the universal claim of foundationalist reason and the traditional definitions of the essence of the human being ("animal rationale", etc.) have become problematic. Understood in this way, it applies not only to openly postmodern or postmetaphysical thinkers like Derrida and Habermas but also to Husserl, whose phenomenological method consists precisely in putting into parentheses the pre-assumptions, not only of traditional metaphysics but also of classical transcendental philosophy.

Our paper is divided into three main sections. We shall first retrace the origins of the growing rift, and ultimately divorce, between the moral and the cultic dimension of religion in occidental thought - a divorce which finds its paradigmatic expression in Kant's Religion within the Boundaries of Mere Reason. In a second step, we shall examine Habermas' reflections on the possible role of religion in a secular society, which are largely indebted to Kant's conception but veer away from it at an important point that reveals both an aporetic aspect of his own philosophical approach and a systematic insufficiency of Kantian philosophy of religion as a whole. In a third and last step, we shall develop a phenomenological interpretation of the dimension of rationality inherent to Christian religious practice and highlight its possible solution potential for certain aporiae and difficulties characteristic of postmetaphysical thought.

\section{The De-Moralization of Signs: Kant's Criticism of Religious Rituals and Its Anthropological Implications}

Although rooted in the inmost dimension of the human soul, religion tends to materialize itself in exterior signs and gestures, which are to establish, express, and confirm the relationship with the divine. Since man is not only a religious but first and foremost a social being, religion also entails, as a rule, ethical commandments governing the relationships with our fellow humans-family members, neighbours, strangers, and so on. An important issue for both religion itself and any subsequent philosophy of religion concerns the systematic relationship between these two aspects. The question is whether and to what extent the relationship with God, which is established through prayers, rituals, etc., can compensate possible shortcomings in the fulfilment of these ethical commands or whether, on the contrary, all religious practices are acceptable to the divinity only insofar as the faithful have respected their ethical duties towards their fellow humans. In the former case, the external rituals directed towards the divine are supposed to repair and re-establish our relationship with other people, whom we may have damaged by an intrinsically condemnable behaviour. In the latter case, by contrast, the external forms of lived faith are considered as invalid if they are contradicted by the intrinsic quality of our behaviour towards our fellow humans. 
The Old Testament offers a paradigmatic testimony for the passage from a primarily ritual-centred form of religious practice to a predominantly ethical orientation of religious consciousness. Especially in the books of the prophets [6], God declares himself disgusted with the sacrifices of animals offered by people who, at the same time, shamelessly oppress the most feeble and helpless members of society, like widows, orphans, impoverished fellow-countrymen, or strangers. This development marks a shift to an interiorized understanding of religion, where the moral quality of man's actions towards other people is not a mere corollary to religious piety but an integral part of his relationship with God. As a consequence, the cultic aspects of religion are not condemned as such but, as expressions of human beings' love towards God, their validity now depends on the degree to which the believers love their neighbour and treat them accordingly.

Kant's philosophy of religion appears as the theoretical radicalization of this primacy of the ethical, which is furthermore fuelled by his Protestant reserve towards the cultic and ritual dimension of the Christian faith. In his Religion within the Boundaries of Mere Reason, as well as in his Critique of Practical Reason, Kant reduces the philosophically relevant meaning of revealed religion to its moral core, which finds its paradigmatic expression in the Ten Commandments without depending, for its categorical validity, on the belief in the revealed character of the latter ([7], pp. 152-56; [8], pp. 232-34). To be sure, Kant has no intention of abolishing religious practice altogether but he considers it legitimate only to the extent that it fosters the moral education of the faithful ([7], pp. 106-107). Therefore, the acceptable elements of religious service are essentially limited to readings from the Bible and preaching, in other words, to those forms of worship where the immediate "teaching" aspect is most visible. By contrast, the symbolic liturgical signs, which-except for baptism and Holy Communion-play a marginal role in Lutheran worship anyway, are put into parentheses and even criticized as residues of an enthusiastic and immature, if not downright superstitious and primitive, form of religion. Kant writes:

"There are, in fact, three different types of delusional beliefs that result from our possible transgressions of the boundaries of our reason with regard to the supernatural (which, according to the laws of reason, is neither an object of theoretical nor of practical use). [...] Third, the delusion that through the use of entirely natural means, we might achieve an effect that remains a mystery to us, i.e., God's influence upon our morality (the belief in means of grace).” ([7], p. 194).

Consequently, the various forms of lived faith typical of the Catholic Church, like attending mass, pilgrimages, the veneration of saints and their holy relics, fasting, indulgences, etc., are qualified by Kant not only as extra-ethical but even as directly unethical insofar as their underlying intention is to "merit" God's grace by specific ritualistic practices rather than by the moral quality of our actions in everyday-life ([7], pp. 167-85). According to Kant, the only legitimate purpose of the different forms of private or public worship is to capture the imagination of the faithful in such a way as to strengthen their moral attitude, it being understood, however, that in the course of time such an external, sensible stimulation should ideally become superfluous. The only philosophically tolerable form of a visible mediation of faith is the person of Jesus Christ, who can be considered as if he were the sensible realization of the idea of moral perfection. This is to say that Jesus' life, actions, and death can serve as a schematism of analogy that does not extend our knowledge of the moral law but merely helps 
convince us of the possibility to live up to its universal requirements in the context of our individual human existence. Kant writes:

"The ideal of a humanity well-pleasing to God (in other words, of such a moral perfection as it is possible for an inner-worldly being subject to needs and inclinations) cannot be represented otherwise than in the idea of a human being [...] because man is unable to gain an understanding of the degree and the intensity of a force such as moral intention, unless he imagines it grappling with obstacles and finally prevailing despite the greatest temptations. Through the practical faith in this Son of God (insofar as he is imagined as if he had assumed human nature), man may hope to become well-pleasing to God (and therefore be blessed)." ([7], pp. 61-62).

In and of itself, however, this schematism does not have an independent ontological value but only gains it a posteriori through the moral quality of the actions it inspires. This is the reason why Kant's Jesus, even in his quality as "Son of God", is not in himself an object of veneration or even adoration outside the sphere of practical reason. The only fully acceptable and thoroughly rational form of "worshipping" him does, therefore, not consist in this or that particular devotional practice but simply in leading a moral life.

Kant considers pure practical reason as perfectly sufficient to found the universal validity of moral principles in this life and limits the task of religion to opening up the eschatological perspective of an ultimate harmonization between universal, moral duty and individual, personal happiness ([7], pp. 161-62). In other words, religion does not contribute anything to the intrinsic determination of the essence of man as rational being but only to the teleological achievement of the ultimate goal of his factual existence. Religion has, therefore, no positive meaning in itself but functions as a gap-filler for a systematic deficiency that cannot be remedied by philosophy alone, i.e., the discrepancy between the final purpose of the moral world and the individual fulfilment of the human subject. But in this perspective, religion precisely remains confined to the realm of purposes rather than being recognized as a phenomenon sui generis that surpasses the teleological schema of means and ends altogether. Its significance is limited to the promise of an ultimate equilibrium between justice and happiness in a "world to come" but its symbolic dimension is still considered by Kant as a merely external, and ultimately superfluous, "garb" of morality rather than a genuine prefiguration and anticipated realization of the overcoming of the discrepancy between the realm of morality and the realm of nature. Kant writes:

"In representing concepts (called ideas) pertaining to morality, which constitutes the essence of all religion, and, therefore, to pure reason, enlightenment consists in distinguishing the symbolic from the intellectual (public worship from religion), the temporarily useful and necessary shell from the thing itself; lest an ideal (of pure practical reason) be exchanged for an idol and the final purpose be missed." ([9], pp. 191-92; [7], pp. 115-24, 192, 197-98).

This somewhat reductionist view on religion is not unproblematic — not primarily from a religious point of view but because it is indicative of a profound dualism in Kant's philosophical conception of the human being as such. The fact that he considers the sensible, symbolical aspect of religious practice as a mere "crutch" that ought to be overcome by a purely rational, intelligible conception of morality translates his difficulty in recognizing that man's physical, bodily dimension may have any positive 
meaning whatsoever apart from its cognitive function as source of sense experience ([9], pp. 140-61). In his Religionsschrift, Kant is at pains to stress that the ultimate root of moral evil is not sensibility but a corrupt will ([7], pp. 34-35). But precisely because sensibility in itself is to be considered as morally neutral, it does not play any intrinsically positive role in Kant's purely intelligible conception of moral religion either but is merely tolerated as a temporary pedagogical concession to human weakness. Ultimately, this approach amounts to a separation between, on the one hand, the transcendentally functionalized subject of pure theoretical and practical reason, and on the other hand, the psychophysical structure of the human being, which becomes a subject of study for empirical, pragmatic anthropology without directly affecting the philosophical concepts of rationality and morality as such. As much as Kant criticizes traditional metaphysics, as much the neat separation between reason as transcendental structure and the empirical, psychophysical dimension of the human person remains tributary to the classical metaphysical dichotomy between the intelligible and the sensible sphere.

This problematic aspect of Kant's approach has imposed a burden on the further development of philosophy in general and philosophy of religion in particular. During the 19th and early 20th century, the initially inner-philosophical distinction between transcendental philosophy and philosophical anthropology evolves into a neat separation between the two disciplines, especially in the neo-Kantian school ([10], pp. 5, 127; [11], pp. 151-58). The more the concepts of "life" and "development" become a privileged object of study for new scientific disciplines like biology, evolutionary theory, and historical sciences, the more transcendental philosophy tends to separate the concept of reason from any genetic, factual, and especially material dimension. Ultimately, this development also affects the role of philosophy in society, since it eventually appears as a purely academic discipline whose gain in new theoretical insights becomes, slowly but steadily, inversely proportional to its life-worldly relevance. The rise of phenomenology at the beginning of the 20th century can be read as an attempt to overcome the dichotomies of classical transcendental philosophy by re-integrating them into the constitutive dynamic of "living consciousness" (Bewusstseinsleben). As the history of German philosophy during the first decades of the 20th century has shown, this new approach to the question of subjectivity has helped develop a new form of philosophical anthropology, especially with regard to human corporeity and psychology ([12], pp. 131, 183; [13], pp. 27-172; [14], pp. 130-234), and opened up a fresh perspective on the phenomenon of religion and religious consciousness [15-17].

The further development of 20th century philosophy and sciences has rendered it even more difficult for non-phenomenological philosophers to tackle the problem of religion on a purely Kantian basis. Important as Kant's philosophical conception of religion might be, it can easily be contested as soon as postmetaphysical thought has rendered problematic, if not demolished altogether, its tacit presuppositions concerning the universality of theoretical and practical reason, as well as the supposed invariability of human nature. Since ethics precisely concerns the productive passage from the sphere of pure practical reason to the sphere of actions in the sensible world, the recent neurobiological and philosophical debate concerning the relationship between man's psychophysical structure and his rational faculty also calls for a renewed examination of the role of sensibility in the genetic development and practical exercise of religious and ethical consciousness. Habermas' reflections on the positive role of religion in modern society are a striking illustration of his awareness of this problem and, at 
the same time, of the difficulties for postmetaphysical thinking to break free from the restricted perspective on religion inherited from classical modern philosophy in general and Kant in particular.

Like Kant, Habermas tends to tacitly identify the general concept of "religion" with the Biblical, Judeo-Christian tradition, especially where the possible positive impact of religious consciousness on society is at stake. He also shares with Kant the fundamental embarrassment about those cultic aspects of the Christian religion that exceed the frame of interpretation provided by cultural Protestantism. However, he takes a more nuanced stance as to the possible meaning of these phenomena and refrains from simply ridiculing them, incomprehensible as they may seem to philosophical reason. His approach is therefore particularly interesting and valuable for those who, without holding themselves a particular religious belief, wish to re-examine the question of religion from a fresh, surprisingly unpolemical perspective.

\section{Habermas' Paradox}

\subsection{The Postmetaphysical Premises of Habermas' Philosophy of Religion}

To Habermas, it is an undeniable fact that philosophy nowadays cannot simply perpetuate the tradition of metaphysical thought or even classical transcendental philosophy. Nevertheless, despite this postmetaphysical premise, Habermas refuses to blur the demarcation line between philosophy and religion and openly criticizes Heidegger and other postmetaphysical authors for their attempts at rethinking the phenomenon of the sacred in completely new terms. It is true that Heidegger, while sharply rejecting any affinity or even synthesis between Christian faith and Greek philosophy, develops a philosophical notion of the divine that conscientiously avoids the characteristic Biblical idea of a transcendent God and creator of the world and advocates the finitude and inner-worldliness of "the gods" or "the heavenly" instead ([15], pp. 97, 135; [18], pp. 5-7; [19], pp. 405-17; [20], pp. 171-74). If Habermas sees these attempts with a critical eye, it is because they precisely do not serve a better philosophical understanding of historical religion but on the contrary, try to re-sacralize philosophy itself in order to immunize it against all rational criticism. Habermas' main objection against this particular type of postmetaphysical thought is therefore aimed at its language, which ultimately replaces discursive, critical argumentation by the pathos of pseudo-religious invocations, and in doing so, places itself outside the sphere of philosophical thought altogether ([1], pp. 28-29).

Habermas is well aware of the fact that the idea of a structural affinity between philosophy and religion is not Heidegger's invention but dates back to Antiquity. In much the same way as modern philosophy, ancient philosophy considers reason as the fundamental, constitutive trait of humanity. Unlike modern philosophy, however, it is much more conscious of the fact that our own personal existence is the first and foremost place where the application of this universal faculty of knowledge to the empirical world has to be put into practice. As a closer look at the different currents and schools of Greco-Roman thought reveals, ancient philosophy considers itself primarily not a theoretical system but a life-form ([21], pp. 13-58). From the beginning of the Hellenist period to late Antiquity, the opposition between philosophy and religion does therefore not align with the dichotomy between pure, theoretical reason and mythically contaminated, practical reason. Instead, both present themselves as integral approaches to human existence, which include theoretical, ethical, and ascetic-practical 
aspects and address themselves not only to man as rational being but to man in all the dimensions of his existence.

Though well aware of this fact, Habermas tries to relativize it by claiming that the existential dimension of philosophy is limited to its "Platonic origins", where one can indeed still discern a "contemplative promise of redemption". The spread of Christianity, however, has led, as he puts it, to a "separation of tasks" between religion and philosophy, the consequence being that from this moment onwards, only the former is responsible for the existentially relevant "knowledge of redemption" (Heilswissen), while the latter limits itself to acquiring and developing a conceptually sound knowledge of the world (Weltwissen) ([22], pp. 49-50). This position reveals an important distinction between Habermas' and Heidegger's respective views on the history of occidental philosophy. Despite his postmetaphysical orientation, Habermas does not wish to reverse the long and complex history of interaction and mutual influence between Greek philosophy and Biblical faith in order to revive a supposedly archaic, world-immanent experience of the divine. Rather, he embraces and accepts the Biblical religion not only as a historical fact but also as a phenomenon secular philosophy has to take seriously in its heterogeneity.

Habermas expressly situates himself in the lineage of Kant as far as the supremacy of enlightened rationality over religious tradition is concerned ([4], pp. 216-19). Consequently, his conception of a renewed dialogue between secular reason and religion is still characterized by a profound asymmetry of the burdens they are entitled to impose on each other and their respective self-understanding ([3], pp. 142-46). Secular philosophy claims, without any further discussion, to represent the higher and purer ideal of reasonable existence, while religion has to justify itself before the court of philosophical reason but has no right to question the latter's legitimacy. Religious consciousness is under the obligation to examine its own theoretical and practical forms of expression and is only allowed to introduce into public discourse what can be translated into the conceptuality forged by secular, modern philosophy ([22], pp. 48-49). This premise essentially banishes all those aspects of religion that include bodily gestures, symbolisms, and materiality since their specific meaning is far more difficult to translate into a cognitive terminology than the doctrinal or ethical dimensions of religion ([4], p. 255). Habermas writes:

"From this perspective, uncomprehended religious traditions and non-understood practices of the religious community life still confront present-day philosophy with insights, intuitions, possibilities of expression, sensibilities, and social manners, which, while not fundamentally alien to public reason, are too enigmatic to be simply accepted into the communicative circulation of society as a whole." ([4], pp. 249-50).

While Kant's criticism of religious cult and rituals is motivated by the potentially unethical consequences of their superstitious misinterpretation, Habermas does not raise the same moral objections but seems to consider this aspect of religion as simply incomprehensible from the point of view of secular reason. To him, philosophical thought has a purely cognitive dimension and hence must not meddle with the religiously connoted "quest for sense". Therefore, without openly polemicizing against it, he seems to consider the whole domain of cult, rituals, and worship as simply extraneous and impenetrable to philosophy. 
Unlike Kant, however, Habermas does not only grant Biblical religion a philosophical meaning from an eschatological perspective but already in the synchronic dimension of life here and now. In his eyes, the significance of religion consists in its capacity to compensate certain semantic shortcomings typical of a thoroughly secularized language, especially where the existential self-understanding of the human being is concerned ([1], pp. 24-25). Under the condition of postmetaphysical thought and postmetaphysical anthropology, Kant's famous question "What is the human being?" is much more difficult to deal with than it used to be two centuries ago. Habermas, therefore, appreciates religion as a particular "language game" or a "special language" ([4], pp. 248, 254) offering a different perspective on humanity, which should be able to be expressed, articulated, and listened to in an open dialogue with secular reason. He writes:

"Pure practical reason can no longer be so sure that it is capable of countering a derailing modernization with no more than insights of a theory of justice in its bare hands. It lacks the creativity of linguistic access to the world, which would be necessary to regenerate from within itself the universally degenerated normative consciousness.” ([4], p. 218).

This affirmation is highly significant insofar as it manifests a certain distance from Kant's thesis of the perfect self-sufficiency of normative, practical reason. But what are the motives for this postmetaphysical modification of classical transcendental philosophy? Partly, it may be due to the fact that for Kant, the main problem of philosophy is not so much the idea of a "derailing modernization" as rather the necessity to assure for the first time the triumph of enlightened rationality in all domains of society. Two centuries later, this very optimistic and even somewhat naïve enthusiasm for a certain ideal of rationality has given way to a more sober and self-critical perspective on the occidental ideal of reason, its blind spots and shortcomings, and its sometimes disastrous consequences. Paradoxically enough, though, the second reason for Habermas' disillusioned view on contemporary practical philosophy is the very consequence of the conscious self-limitation, if not self-deconstruction, of occidental rationality itself. The identification of reason with its discursive, linguistic dimension has rendered the ideal of rationality fragile to an extent quite unimaginable for Kant and his immediate posterity, and in doing so, obliged philosophy to thoroughly rethink and re-establish the relationship between pure practical reason and the sphere of ethical actions.

\subsection{The Difficulty of Embodied Reason in Habermas' Philosophical Approach}

Significantly enough, Habermas' renewed interest for religion is motivated by an ethical problem that concerns precisely not primarily the rational, discursive dimension of human beings, nor the resulting forms of social communication, but their fundamental bodily, material constitution. In his famous speech Glauben und Wissen ("Faith and Knowledge"), Habermas expresses the hope that the Biblical notion of man as "God's image" might provide a critical corrective for the potentially disastrous consequences of certain biotechnological developments, whose objective is to genetically reshape or even completely recreate humanity's physical and mental properties ([1], pp. 29-30). Although Habermas does not subscribe to the theological or metaphysical meaning of this Biblical expression, he is convinced that it could be useful to emphatically recall a negative limit with regard to man's right to interfere in the biological process of engendering other human beings. It is noteworthy, 
however, that Habermas' Biblical quotation of man as "God's image" refers to the first creation account in Genesis 1:26-27 and not to the second account in Genesis 2:7. Since Philo of Alexandria and the Church Fathers, the exegetical tradition has interpreted these two different descriptions of the creation of man as referring to the rational, intellectual dimension of the "inner man" (Gen 1:26-27) and the physical, bodily structure of the "outer man" (Gen 2:7) respectively ([23], I.4-5, pp. 64-66). Why, then, should the first creation account be a more useful image to protect the genetic disposition of the human body against biotechnological manipulation than the second, which insists more on man's earthly body as being directly modelled by God and inspired by the divine breath of life?

The manifest difficulty in attributing a positive philosophical meaning to human corporeity is indicative of an intrinsic tension, and maybe even contradiction, in Habermas' approach. Secular reason claims to be the sole judge of the rationally acceptable contents of religion but, at the same time, apparently lacks confidence in its own capacity to enforce certain norms aiming at a self-limitation of biotechnological development. He writes:

"Postmetaphysical thought alone may well tackle [...] the defeatism of reason. But the situation is different with practical reason which, without the support of a philosophy of history, is bound to despair of the motivating force of its own good reasons because the tendencies of a derailing modernization do not so much comply with its morality of justice but counter it." ([22], p. 51).

Since religion, according to Habermas, is only partially translatable into a conceptuality understandable for secular reason, it appears to be no more than a partial expression of the rationality non-religious philosophy claims to represent in its entirety. Therefore, it is hard to understand why religion should have more success in sensitizing people to certain bioethical problems than secular reason. This expectation would only be understandable under the premise that religion does not only dispose of a richer linguistic potential but also of more effective methodical instruments when it comes to the internalization and practical application of ethically relevant insights. But this would amount to secular philosophy admitting that it has, in some respect, lost touch with the existential dimension of human life orientation and is therefore unable to have an impact on people's ethical choices.

Habermas seems to be on the fence when it comes to the supposedly "irrational", i.e., extra-cognitive elements of religious practice. He writes: "Faith retains something opaque for knowledge, which may neither be denied nor simply accepted." ([4], p. 50). Remarkably enough, though, it is not a purely philosophical "religion of reason" (Vernunftreligion) in the Kantian sense but the lived faith of religious people, which Habermas hopes can provide the existentially relevant surplus that may prevent secular reason from sliding into trivial naturalism or resigned defeatism ([24], p. 181). This seems to suggest that what Habermas calls the "opaque" dimension of religion actually covers two different phenomena: on the one hand, it can refer to the lack of cognitive translatability of "infallible revealed truths", insofar as these are intended to be immunized against rational discussion and critical questioning ([3], pp. 135, 149). In this case, the lack of transparency is only a privative and, therefore, relative one. In many cases, in fact, and especially in the case of Christian theology, the contents of religious doctrines can very well be rendered intelligible in cognitive terms, the claim of their revealed character having no other objective than to protect and reinforce their existential truth-value. On the other hand, however, the "lack of transparency" can also refer to the visible transposition of religious 
convictions in bodily, sensible gestures, and ritual practices. In this instance, it acquires an essential quality since the material, sensible dimension of religious cult and lived faith points towards the undissolvable opacity of the human body that carries structures of meaning whose specific rationality exceeds the boundaries of the "cognitive" sphere in the narrow sense.

Habermas' difficulty at seeing in the more-than-cognitive dimension of religion more than just a "lack of transparency" can be interpreted as a consequence of the traditional Kantian dichotomy between transcendental subjectivity and physical embodiment — a dichotomy which his own attempt to promote "detranscendentalized" rationality does not really succeed in eliminating. The "strong" constitutional claim traditionally associated with the concept of transcendental reason is replaced by a "weaker" form of rational discourse, which is supposed to unfold in the factual communication community between human beings. However, Habermas unilaterally limits the mode of communication to the verbal, linguistic dimension and thus perpetuates, albeit in a postmetaphysical mode, the traditional dichotomy between logically founded, "transparent" reason and a supposedly "blind" sensibility that can only be grasped and rendered comprehensible through conceptual, categorical knowledge ([9], pp. 144-45). This emphasis on the supra-sensible dimension of rationality seems all the more paradoxical, since he complains at the same time about the inability of postmetaphysical thought to effectively intervene in the problematic discussion concerning the possible genetic manipulation of the human body.

It seems to us that this intrinsic contradiction is the consequence of Habermas' disembodied conception of discursive reason as such, which results in his problematic identification of the "semantic potential" of religion with its "cognitive contents". Habermas is perfectly justified in rejecting the Heideggerian idea of charging philosophy with a pseudo-religious form of sacrality and spirituality. This does not answer the question, however, of whether the sacral dimension practiced within religion has to be considered as the radical opposite of discursive reason or whether, on the contrary, it might perhaps be the expression of a specific, existentially rooted form of rationality that offers possible answers to the aporetical aspects of practical reason Habermas has diagnosed with regard to postmetaphysical philosophy. In the following section, we shall develop our thesis that religious practice might offer an alternative, non-mythological interpretation of the relationship between human reason and human embodiment, which may not only close the Kantian rift between the cultic and the moral dimension of religion but also expand Habermas' conception of "discursive rationality" beyond the boundaries of verbal discussion. Since Habermas' reflections on religion put a particular focus on the Biblical religious tradition, and with regard to the fact that it would be rather difficult to talk about religious cult in general, we shall limit our analyses to the traditional forms of Christian piety and Christian worship. They are meant as a paradigmatic example for a possible phenomenological interpretation of the rational content of religious rituals, without making any normative claim concerning other religious traditions and their possible philosophical meaning. 


\section{Beyond Language: the Intrinsic Relationship between Christian Rituals and the Ancient Philosophical Concept of Reason}

\subsection{Ancient Philosophy as Life-Form and Its Perception by the Biblical Tradition}

Contrary to what is often affirmed ([25], pp. 213-21; [26,27]), Christian liturgy and religious practice shows much less affinity to ancient pagan religions than to ancient thought. As a matter of fact, the first serious attack against the traditional Greco-Roman religion does not come from early Christianity but from within Greek philosophy itself. From the Pre-Socratic Xenophanes onwards [28], the open and sometimes quite ironic critique of the Homeric gods and the traditional forms of religion has become a real leitmotiv in ancient thought. This does not mean, however, that for the philosophers of Antiquity, there is no such thing as an ultimate, divine principle of the world. Simply, they try to rethink it in a more rational, dignified manner so as to make it compatible with the exigencies of rigorous philosophical thought ([29], I.1-19, pp. 1-21). At the same time, the philosophical concept of reason does not simply reduce the world to a "profane" sphere of mere objects. Of course, natural phenomena are to be observed, analyzed, and given a rational explanation, but even this form of theoretical knowledge is never completely disconnected from the philosopher as a human person.

The Heraclitean, and later Stoic, idea of logos as an immanent, all-embracing principle of reality allows man to understand himself as a rational being without perceiving the cosmos as a heterogeneous, naturalistic entity. The right exercise of his capacity of reasoning should therefore enable him to recognize and fill the place assigned to him in the equally rational context of reality [30]. The expression "rational nature" has therefore a double meaning: it refers, firstly, to the specific trait of man as a rational being and secondly, to the latent rational character of the cosmos, which expresses itself through universal constants and natural laws ([31], pp. 533-34; [32], p. 193). Man and world are therefore not opposed as free, reasonable existence on the one hand and a blind, naturalistic mechanism on the other but as conscious, self-aware reason and latently active reason, which are to be coordinated with one another.

Such a correspondence between humanity and the rest of nature is possible because rationality, understood as logos, is not conceived as an abstract, homogeneous sphere of thought but rather as a dynamic relationship that unfolds in rhythmic articulations and includes the whole psychophysical dimension of the human being ([32], p. 199). This relationship is not primarily of a conceptual, linguistic kind but expresses itself as a proportion between numbers. Both the Greek word logos and the Latin word ratio, in fact, have the original meaning of a relationship between two integers ([33]; [34], 507 E-F). Therefore, already the regularities of the celestial bodies and of astronomical events, the cyclical change of the seasons, or the various stages of human life and its characteristic changes are so many examples of the implicit rational articulation of reality, which unfolds in front of man's eyes even before being conceptualized in language. This original meaning of logos as rhythm and harmony prevents reason from being completely cut off from the dimensions of temporality and materiality. Far from being a static "faculty of knowledge", logos appears as a schematism that allows man to align the various dimensions of his existence with the rational structures of the cosmos, which manifest themselves to him. Perhaps the most explicit theoretical exposition of this idea is to be found in Plato's Timaeus, where the composition of the world itself is not seen as a mechanical assemblage of material 
components but rather as a harmonious coordination of the various material elements of the cosmos, as well as of the "soul" that animates it ([35], 31 b 5-32 c 4; 34 a 9-37 c). By conceiving the world itself as a well-proportioned and well-attuned living being, Plato can convincingly argue that for human beings too reasonable life does not consist in a purely intellectual exercise but rather in establishing an equilibrium between the various dimensions of their existence in conformity with the cosmic harmony surrounding them ([35], $89 \mathrm{~d} 3-90 \mathrm{~d}$ 7).

The regularities of this fundamental Law of nature are not only to be observed in a merely esthetical or scientific attitude but call for an equally regular ethical reflection which, especially in the philosophical currents of Pythagoreanism and Stoicism, takes the form of a full-fledged ascetic exercise, i.e., an examination of conscience that is to be practiced every evening ([36], III.36.1, pp. 296-98). This ritual enables the philosopher to not only live his life as a continuum but to regularly interrupt it in order to become aware of his specific tendencies, his personal strengths and weaknesses, the mechanisms that guide his actions, and so on. However, this philosophical ritual is a strictly individual exercise and does not involve a cultic community. It is small wonder, therefore, that many ancient philosophers are known to have developed an extremely rational conception of the divine while still participating in the rites and sacrifices of the official Greco-Roman religion, which they tried to re-interpret in a rational, metaphorical way. However, the distinction between private philosophical rituals in the narrow sense and the participation in public worship according to the rules of traditional religion was never completely eliminated ([37], XXVIII.148-156, pp. 130-36; [38], VIII.13.20-22, pp. 320-42).

Ever since the first encounter of the Biblical tradition with ancient Greek culture during the Hellenistic period, both Jewish and Christian authors have paid particular attention to the philosophical notion of logos as intelligible proportion, rhythm, and harmony when trying to establish a positive systematic connection between pagan thought and their own Biblical faith. It is not the rather colourful deities of traditional Greek religion but rather Greek philosophy and its fundamental idea of a rationally structured cosmos that they perceive as an equivalent of their own conception of a world created by divine wisdom and ruled by divine providence ([39], I.1-VI.25, pp. 6-20). The structural, formal element of philosophical logos also represents the common denominator of pagan thought and early Christian liturgy. Clement of Alexandria, for example, emphasizes the role of music for both human paideia in general and Christian worship in particular. While he deems not just any form of music suitable for bringing out the best in human beings, he strongly advocates the use of music in Christian liturgy in order to establish a harmonious balance between the different parts of the soul and to increase the ability of the faithful to conform their whole lives to the ethical requirements of the logos ([40], pp. 257-58, 268-70, 276-77, 279-80).

This does not mean, however, that the problematic relationship between the ethical and the cultic dimension of religious practice is no longer an issue for the Christian faith. On the contrary, the awareness of this problem is already plainly visible in the New Testament. According to Matthew 5:23, the reconciliation of the faithful with his brother who holds a grudge against him is the pre-condition for his sacrificial offering to be acceptable to God, not the other way around. This implies, of course, that there still is such thing as a sacrificial practice to be observed, but its significance is visibly relativized and soon definitively overcome by Jesus' self-sacrifice on the cross, where the love towards God and the love towards humanity eventually coincide. This event marks a 
radical internalization and ethical sublimation of the sacrificial practice as such. From the Christian point of view, the relationship with God is no longer established and nourished by sacrificing "something" (living animals, bread, flour, oil, etc.) but by offering up one's own existence and allowing it to be consumed for the benefit of humanity.

As a consequence, Christian liturgy is no longer intended to remediate a fundamental lack in people's relationship with God but to celebrate its fulfilment. The various forms of public and private worship no longer have the objective to earn the faithful God's benevolence but to unfold and illustrate the goodness he has shown to them far beyond their merit. The primary aim of Christian liturgical practice is therefore not to "influence" God himself, so that he may be well-disposed towards humanity, but rather to dispose people's hearts and minds in such a way that they may fully understand the gratuity of their relationship with God and make their lives the expression of this overflowing goodness. This, of course, does in no way diminish the importance of the ethical dimension in early Christian religion. In James 2:1-18, the respectful and merciful behaviour towards the poor and indigent is considered to be not only the decisive criterion of truth for the Christian faith but also the necessary condition for any religious assembly to be agreeable in God's eyes. Ethics is therefore the prerequisite for the worthy celebration of Christian liturgy, but it does not exhaust the totality of its meaning. From an internal, theological perspective, liturgy is meant to express the playful joy of Christian consciousness, which knows itself definitively redeemed and liberated by Christ and intends no more than to celebrate this abundance of gracious salvation through gestures and rites that are intrinsically meaningful but devoid of any extrinsic, objective scope ([41], pp. 44-58; [42], pp. 57-67). However, does this mean that from an external perspective that does not share this theological conviction, Christian liturgy has to be considered as a strange and incomprehensible phenomenon, which has nothing to say to philosophical reason?

\subsection{Calibrating the Self: A Phenomenological Interpretation of Christian Religious Practice}

We would like to argue that even from the viewpoint of secular reason, Christian religious practice can be perceived as endowed with a meaning whose validity does not depend on the personal acceptance of the Christian faith as a belief system. Rather, its possible significance lies in its ability to integrate the various aspects and dimensions of human existence, which both ancient and modern philosophy tend to separate. With the rise of Christianity, the ancient conception of philosophical life orientation and life practice is not abolished altogether but rather enriched by an additional dimension that closes the gap between "philosophical religion" and "public religion" ([43], pp. 55-72). In fact, the idea of the Incarnation implies that the rational, proportional, and harmonious conformation of man's existence in accordance with the divine Law is not only expressed in a rhythmic, mathematical structure but also includes certain material substrates (water, wine, bread, oil, salt, etc.), which are not simply singular objects but represent, at a smaller scale, the dynamic interaction between the divine logos and the human flesh it assumed [44,45].

Contrary to what many modern philosophers of religion tend to think, this strong sensible element of the Christian faith (especially in its Catholic or Orthodox form) is not synonymous with a relapse into a primitive mythological world-view. Rather, it is the result of the conviction that, in order for man to act morally, he needs to continually re-establish the connection between the intellectual and the 
sensible, physical dimension of his existence through certain rituals and exercises. These forms of religious practice do not directly possess an ethical quality in themselves, but - contrary to what Kant affirms - they are not necessarily animated by the superstitious and unethical desire to exercise an "influence" upon the divinity either. On the contrary, their objective is to make man aware again and again of the different dimensions of his existence - temporality, spatiality, sensibility, imagination, and reason - and to teach him to pass from one level to another by means of certain cultic or liturgical gestures, actions, and "objects" in a broad sense, which possess an equally complex temporal, spatial, and material articulation ([46], pp. 19-63). Under this perspective, these religious rites and objects of piety do not have a merely esthetical meaning [47] but can be qualified as proto-ethical schematisms that help habitualize the productive synthesis between pure practical reason and the sensible sphere. The domain of ethical consciousness, in fact, does not only start with the application of the universal moral law to concrete situations and actions but already with establishing the awareness of the living synthesis and possible dynamic interaction between the various aspects of our existence.

Both Kant's and Habermas' approaches tend to forget that the human body in its organic materiality is not only a source of sense data for our theoretical knowledge of the world but the necessary "interface" between pure practical reason and the objective world. They seem to take for granted the possibility for human beings to translate the decisions of their will into appropriate actions, as if the various rational and psychophysical dimensions of the human person were perfectly attuned and connected to one another right from the beginning. As Husserl's phenomenological analyses have shown, however, the interconnection between theoretical and practical reason on the one hand and the bodily structure of the human being on the other is not simply given but is the product of a progressive self-constitution of embodied transcendental consciousness ([12], pp. 99-121). In order to perceive my hand as $m y$ hand, I do not only have to look at it as physically connected with the rest of my body, but I repeatedly have to experience the possibility to grasp material objects and bring about visible changes in the natural world. In doing so, I become aware of the fact that my body is not simply a part of the objective world but the subjective proto-organ of all possible connections between my consciousness and the objective world, and especially of the active, spontaneous potency of the "I can" (ich kann) ([48], pp. 154-69). Unlike Kant, Husserlian ethics no longer simply affirms "You can, because you must" but rather "You can, because you are embodied consciousness".

However, this constitutive self-synthesis of transcendental consciousness and its organic body has to be experienced and re-experienced in order to maintain its unity. Even when the connection between our consciousness and our body has become habitualized to the point that we do not consciously need to reflect upon it, it needs to be regularly reconfirmed by appropriate tactile and kinesthetic experiences. If we apply the ancient Latin meaning of reason as ratio, i.e., a proportional relationship between two variables, we could say that in Husserlian phenomenology, the first and most fundamental expression of reason consists in the pre-linguistic, synthetic relationship between living consciousness and its own living body, a relationship that "de-naturalizes" the body in a double, positive sense: first, by appropriating it as an essential part of pure monadic consciousness and second, by proving its being the transcendentally necessary presupposition for any inter-subjective, ethical relationship ([49], pp. 19-22, 88-95, 251-58). Notwithstanding the strong transcendental orientation of Husserl's phenomenology, one could argue that he is indeed much closer to the fundamental insights of postmodern philosophy than Habermas. In fact, Husserl does not presuppose the bodily 
structure of human beings as a natural concomitant of their rational consciousness but interprets the unity of these two dimensions as the result of a synthesis, which, despite its gradual habitualization, remains characterized by a certain fragility. In order for man to maintain and confirm his ability to accomplish teleological acts in the external world, he has to experience, and continue to experience, the teleological interplay between the strictly immanent sphere of his stream of consciousness and the first immanent exteriority, or transcendence, of his body.

In a slightly provocative manner, one could say that Christian religious practice is much more akin to this type of Husserlian postmetaphysical thinking than to classical metaphysics or Kantian transcendental philosophy. In fact, the Christian faith does not consider the conscious, harmonious interplay of the various dimensions of the human being as given, but as something that has to be gained, maintained, and nourished through a variety of liturgical and devotional practices. From a phenomenological point of view, the often-ridiculed forms of popular piety, which typically consist of rhythmical prayers, like processions, litanies, or the recitation of the rosary, can be interpreted as the visible expression of the dynamic synthesis between an intelligible, ethically relevant content (various persons of the history of salvation, certain episodes in Jesus' life, specific doctrinal aspects of the Christian faith) and a temporal, spatial, and material structure (i.e., rhythmically punctuated prayers and invocations; regular changes of bodily postures, like kneeling, standing, prostrating oneself; tactile experiences, like grasping the strand of prayer beads, etc.). Certainly, there is always the risk that the faithful may misinterpret their actions as being necessary for "earning", and therefore "meriting", the divine grace. However, this erroneous interpretation of religious practice is by no means inevitable.

From an external, philosophical perspective, one can just as well focus on an even more important, mostly a-thematic aspect of these rituals, i.e., the productive synthesis between the intelligible and the sensible sphere, which is accomplished through the bodily gestures of the faithful—a synthesis that helps habitualize the spontaneous passage from the level of pure practical reason to the world of sensible objects and actions, which is primordial for ethical practice. What Christian religious rituals have to offer to philosophical thought is therefore not a separate cognitive content but a pre-discursive and perhaps more promising way of connecting the cognitive and the sensible dimension of the human being in a proto-ethical framework. They may indeed seem "opaque" and incomprehensible as long as they are considered as isolated objects, but they become intelligible once they are recognized as dynamic relationships produced by a pre-linguistic, embodied form of logos.

\section{Conclusions}

After this analysis of the possible phenomenological meaning of Christian religious rites and cultic practices, we are able to perceive Habermas' preoccupations concerning the possible aberrations of unbridled biotechnological progress in a new light. While he is quite right in assuming that lived religion may offer a valuable resource against these ethically questionable scientific developments, its positive contribution is situated in a different domain than he thinks. Of course, religious language in general, and the language of the Bible in particular, has a symbolic force and a compelling existential dimension ordinary philosophical conceptuality can hardly compete with. However, by limiting his philosophical view on religion to its linguistic, cognitive contents, Habermas deprives himself of the possibility to understand how and to what extent religion may contribute to deal with the problems of 
postmetaphysical anthropology and ethics. He is justly afraid of the serious problems a deliberate genetic "redesign" of the human being could pose in terms of freedom, dignity, and independence. But the most powerful counter-paradigm to this unscrupulous idea of absolute feasibility is not so much the Biblical concept of man as "God's image" but the Paulinian idea of a "new creation" in Christ [50]. From a phenomenological point of view, this theological expression could be interpreted as saying that a radically new paradigm of humanity is not to be achieved through an external manipulation of man's physical, genetic disposition but through a harmonious recalibration of his pre-given physical, psychic, and intellectual disposition according to the rhythm of pre-discursive reason (logos). The only legitimate and non-oppressive form such a "new creation" can take is, therefore, not the production of new human "objects" or "substrates" but the creation of new relationships, firstly, between the various dimensions of individual human existence, and secondly, between all human beings as members of a universal community of embodied reason.

Habermas seems to understand intuitively that the positive ethical potential of lived faith has to do with those religious practices that exceed the realm of discursive reason in the narrow sense. However, by simply qualifying them as "opaque", he precludes himself from all possibility to gain a positive understanding of their underlying logic. On the one hand, he seems to yearn for a philosophical equivalent of the inviolability, not only of the individual human body but also of the universal genetic "code" (the pre-discursive logos) it carries. On the other hand, however, he seems to ignore that in the theological context of Biblical, and especially Christian religion, this inviolability is not the $a$ posteriori result of rational communication between human subjects. Rather, it is derived from the idea that the divine logos, in assuming human nature on an ontological and, therefore, pre-linguistic level, has placed the essence of humanity - and this means not only man's "immortal soul" but also and above all his bodily, physical dimension - beyond the grip of any external, utilitarian optimization. What Christian religious practice and liturgy does is no more than to repeat and recall this fact to the faithful by offering them public and private rituals, whose specific rhythmic and sensible articulation is intended to establish and maintain in them the embodied rationality of this "new creation".

If postmetaphysical thought is indeed as bereft of concrete ethical influence on people's lives as Habermas claims it to be, it should perhaps try to overcome its unilateral and reductionist identification of rationality with linguistic discourse. Even for secular forms of philosophy it is quite possible to regain, at least on a phenomenological basis, an integral perspective on the human being, which considers the living body not as a mere appendix to communicative reason but rather as the necessary place of connection with the inter-subjective "world for all" that is the horizon of all ethical actions. Since postmetaphysical anthropology no longer offers a clear answer to the question "What is the human being?", postmetaphysical ethics should, perhaps, try to make people aware of the dynamic interplay between the different dimensions of their existence — body, sensibility, imagination, will, and reason - by punctuating, at each of these levels, the continuum of nature by specific actions, symbols, and gestures whose non-utilitarian yet meaningful character performatively represents humanity's being an end in itself. Christian religious rituals are, in essence, no more than specific inner-worldly places that celebrate the overcoming of the logic of utilitarianism through certain temporal, spatial, and material rhythms, which break the natural continuity of the cosmos only in order to reveal it as the future terrain for free and responsible ethical actions ([51], pp. 7-48). 
We may, therefore, be justified in concluding that Habermas' almost nostalgic "awareness of what is missing" refers, in fact, not so much to the supplementary linguistic potential of religious discourse as rather to the yearning of communicative rationality for a new and still unexpected form of postmetaphysical incarnation.

\section{Acknowledgements}

This work has been supported by the Austrian Science Fund (FWF), Grant number P27499-G15.

\section{Conflicts of Interest}

The author declares no conflict of interest.

\section{Abbreviations}

AA: Akademie-Ausgabe (for the collected works of Immanuel Kant);

Hua: Husserliana edition (for the collected works of Edmund Husserl);

GA: Gesamtausgabe (for the collected works of Martin Heidegger);

DK: Diels-Kranz (for the collective edition of the fragments of the Pre-Socratics).

\section{References}

1. Jürgen Habermas. Glauben und Wissen. Frankfurt a. M.: Suhrkamp, 2001.

2. Jürgen Habermas. "Vorpolitische Grundlagen eines demokratischen Rechtsstaates?” In Zwischen Naturalismus und Religion. Frankfurt a. M.: Suhrkamp, 2005, pp. 106-18.

3. Jürgen Habermas."Religion in der Öffentlichkeit". In Zwischen Naturalismus und Religion. Frankfurt a. M.: Suhrkamp, 2005, pp. 119-54.

4. Jürgen Habermas. "Die Grenze zwischen Glauben und Wissen. Zur Wirkungsgeschichte und aktuellen Bedeutung von Kants Religionsphilosophie". In Zwischen Naturalismus und Religion. Frankfurt a. M.: Suhrkamp, 2005, pp. 216-57. (All translations are by Martina Roesner).

5. The inability of philosophy to adequately deal with the phenomenon of rituals is discussed by Johann Figl. "Religiöse Rituale_Ein unbewältigtes Thema der Philosophie”. In Rituale. Zugänge zu einem Phänomen. Edited by Florian Uhl and Arthur R. Boelderl. Düsseldorf and Bonn: Parerga Verlag, 1999, pp. 187-205.

6. See, e.g., Is 1:11-17; Hos 6:6.

7. Immanuel Kant. Religion innerhalb der Grenzen der bloßen Vernunft [Religion within the Boundaries of Mere Reason]. AA VI. Berlin: Walter de Gruyter, 1968. (All translations are by Martina Roesner).

8. Immanuel Kant. Kritik der praktischen Vernunft [Critique of Practical Reason]. AA V. Berlin: Walter de Gruyter, 1968.

9. Immanuel Kant. Anthropologie in Pragmatischer Hinsicht [Anthropology from a Pragmatic Point of View]. AA VII. Berlin: Walter de Gruyter, 1968. (All translations are by Martina Roesner; emphasis is Immanuel Kant's). 
10. Hermann Cohen. Das Prinzip der Infinitesimalmethode und seine Geschichte. Berlin: Dümmlers Verlagsbuchhandlung, 1883.

11. Heinrich Rickert. Philosophie des Lebens. Darstellung und Kritik der philosophischen Modeströmungen unserer Zeit. Tübingen: Mohr, 1920.

12. Edmund Husserl. Cartesianische Meditationen und Pariser Vorträge. Hua I. The Hague: Nijhoff, 1950.

13. Edmund Husserl. Ideen zu einer reinen Phänomenologie und phänomenologischen Philosophie, Zweites Buch. Hua IV. The Hague: Nijhoff, 1952.

14. Edmund Husserl. Phänomenologische Psychologie. Hua IX. The Hague: Nijhoff, 1962.

15. Martin Heidegger. Phänomenologie des religiösen Lebens. GA 60. Frankfurt a. M.: Klostermann, 1995.

16. Gerda Walther. Phänomenologie der Mystik. Olten: Walter-Verlag, 1976.

17. Käte Oltmanns. Meister Eckhart. Frankfurt a. M.: Klostermann, 1935.

18. Martin Heidegger. Einführung in die Metaphysik. Tübingen: Niemeyer, 1987.

19. Martin Heidegger. Beiträge zur Philosophie [Vom Ereignis]. GA 65. Frankfurt a. M.: Klostermann, 1994.

20. Martin Heidegger. Vorträge und Aufsätze. Stuttgart: Neske, 1994.

21. Pierre Hadot. Exercices spirituels et philosophie antique. Paris: Institut des Études Augustiniennes, 1981.

22. Jürgen Habermas. "Ein Bewusstsein von dem, was fehlt". In Die Religionen und die Vernunft. Die Debatte um die Regensburger Vorlesung des Papstes. Edited by Knut Wenzel. Freiburg: Herder, 2007. (All translations are by Martina Roesner).

23. Philo of Alexandria. Quaestiones et solutiones in Genesim. In Les Cuvres de Philon d'Alexandrie. Introduced, translated and annotated by Charles Mercier. Paris: Les Éditions du Cerf, 1979, vol. 34 A.

24. Gesche Linde. “'Religiös' oder 'säkular'? Zu einer problematischen Unterscheidung bei Jürgen Habermas". In Moderne Religion? Edited by Knut Wenzel and Thomas M. Schmidt. Freiburg and Basel and Wien: Herder, 2009, pp. 153-202.

25. Christoph Auffarth. "'Licht vom Osten'. Die antiken Mysterienkulte als Vorläufer, Gegenmodell oder katholisches Gift zum Christentum”. Archiv der Religionsgeschichte 8 (2006): 206-26.

26. Johannes Leipoldt. Von den Mysterien zur Kirche. Gesammelte Aufsätze. Leipzig: Koehler \& Amelang, 1961.

27. Herman von Skerst. Der unbekannte Gott. Griechische Mysterienschau und christliche Erfüllung. Stuttgart: Verlag Urachhaus, 1967.

28. Xenophanes. DK 21 B 11; DK 21 B 12; DK 21 B 14; DK 21 B 15; DK 21 B 16; DK 21 B 17. In Die Fragmente der Vorsokratiker. Edited by Hermann Diels and Walther Kranz. Zürich and Berlin: Weidmannsche Verlagsbuchhandlung, 1964.

29. Marcus Tullius Cicero. De natura deorum. Edited by Wilhelm Ax. Stuttgart: Teubner, 1980.

30. Heraclitus. DK 22 B 2; DK 22 B 30; DK 22 B 72; DK 22 B 11. In Die Fragmente der Vorsokratiker. Edited by Hermann Diels and Walther Kranz. Zürich and Berlin: Weidmannsche Verlagsbuchhandlung, 1964.

31. Karl Deichgräber. Rhythmische Elemente im Logos des Heraklit. Wiesbaden: Franz Steiner, 1963. 
32. Johannes Lohmann. "Musikê und Logos." In Logos. Theorie und Begriffsgeschichte. Edited by Lorenzo Perilli. Darmstadt: Wissenschaftliche Buchgesellschaft, 2013, pp. 193-205.

33. Pythagoras. DK 58 B 35; DK 58 B 41. In Die Fragmente der Vorsokratiker. Edited by Hermann Diels and Walther Kranz. Zürich and Berlin: Weidmannsche Verlagsbuchhandlung, 1964.

34. Plato. Gorgias. Translated by Friedrich Schleiermacher. Edited by Dietrich Kurz and Gunther Eigler. Darmstadt: Wissenschaftliche Buchgesellschaft, 1981.

35. Plato. Timaeus. Translated by Friedrich Schleiermacher. Edited by Dietrich Kurz and Gunther Eigler. Darmstadt: Wissenschaftliche Buchgesellschaft, 1981.

36. Lucius Annaeus Seneca. De ira. Edited by Manfred Rosenbach. Darmstadt: Wissenschaftliche Buchgesellschaft, 1989.

37. Iamblichos. Vita Pythagorica. Edited and translated by Michael von Albrecht. Darmstadt: Wissenschaftliche Buchgesellschaft, 2002.

38. Diogenes Laertius. Vitae philosophorum. Edited by Robert D. Hicks. London: William Heinemann; Cambridge (Mass.): Harvard University Press, 1958.

39. Philo of Alexandria. De opificio mundi. In Philo. Works in Ten Volumes, vol. I. Edited by Francis H. Colson and George H. Whitaker. London: William Heinemann; Cambridge (Mass.): Harvard University Press, 1956.

40. Charles H. Cosgrove. "Clement of Alexandria and Early Christian Music". Journal of Early Christian Studies 14 (2006): 255-82.

41. Hugo Rahner. Der spielende Mensch. Einsiedeln: Johannes Verlag, 1952.

42. Romano Guardini. Vom Geist der Liturgie. Paderborn: Grünewald-Verlag, 2007.

43. Hugo Rahner. Griechische Mythen in christlicher Deutung. Zürich: Rhein Verlag, 1945.

44. Michel Henry. C'est moi la vérité. Pour une philosophie du christianisme. Paris: Éditions du Seuil, 1996.

45. Michel Henry. Incarnation. Paris: Éditions du Seuil, 2000.

46. Paul de Clerck. L'intelligence de la liturgie. Paris: Les Éditions du Cerf, 1995.

47. Hermann Nitsch. "Ritual als ausdrucksform der kunst." In Rituale. Zugänge zu einem Phänomen. Edited by Florian Uhl and Arthur R. Boelderl. Düsseldorf and Bonn: Parerga Verlag, 1999, pp. 103-13.

48. Edmund Husserl. Ding und Raum. Hua XVI. The Hague: Nijhoff, 1973.

49. Edmund Husserl. Die Lebenswelt. Auslegungen der vorgegebenen Welt und ihrer Konstitution. Hua XXXIX. Dordrecht: Kluwer, 2008.

50. See 2 Cor 5:17.

51. Jean-Yves Lacoste. Expérience et Absolu. Questions disputées sur l'humanité de l'homme. Paris: Presses Universitaires de France, 1994.

(C) 2015 by the author; licensee MDPI, Basel, Switzerland. This article is an open access article distributed under the terms and conditions of the Creative Commons Attribution license (http://creativecommons.org/licenses/by/4.0/). 